University of Nebraska - Lincoln

DigitalCommons@University of Nebraska - Lincoln

Agronomy \& Horticulture -- Faculty Publications

Agronomy and Horticulture Department

2012

\title{
Cover Crop Mixtures for the Western Corn Belt: Opportunities for Increased Productivity and Stability
}

\author{
Samuel E. Wortman \\ University of Nebraska-Lincoln, swortman@unl.edu \\ Charles Francis \\ University of Nebraska-Lincoln, cfrancis2@unl.edu \\ John L. Lindquist \\ University of Nebraska-Lincoln, jlindquist1@unl.edu
}

Follow this and additional works at: https://digitalcommons.unl.edu/agronomyfacpub

Part of the Plant Sciences Commons

Wortman, Samuel E.; Francis, Charles; and Lindquist, John L., "Cover Crop Mixtures for the Western Corn Belt: Opportunities for Increased Productivity and Stability" (2012). Agronomy \& Horticulture -- Faculty Publications. 614.

https://digitalcommons.unl.edu/agronomyfacpub/614

This Article is brought to you for free and open access by the Agronomy and Horticulture Department at DigitalCommons@University of Nebraska - Lincoln. It has been accepted for inclusion in Agronomy \& Horticulture -Faculty Publications by an authorized administrator of DigitalCommons@University of Nebraska - Lincoln. 


\title{
Cover Crop Mixtures for the Western Corn Belt: Opportunities for Increased Productivity and Stability
}

\author{
S. E. Wortman,* C. A. Francis, and J. L. Lindquist
}

\begin{abstract}
Achieving agronomic and environmental benefits associated with cover crops often depends on reliable establishment of a highly productive cover crop community. The objective of this study was to determine if cover crop mixtures can increase productivity and stability compared to single species cover crops, and to identify those components most active in contributing to or detracting from mixture productivity. A rainfed field experiment was conducted near Mead, NE, in 2010 and 2011. Eight individual cover crop species (in either the Brassicaceae [mustard] or Fabaceae [legume] family) and four mixtures of these species (two, four, six, and eight species combinations) were broadcast planted and incorporated in late March and sampled in late May. Shoot dry weights were recorded for sole crops and individual species within all mixtures. Sole crops in the mustard family were twice as productive $\left(2428 \mathrm{~kg} \mathrm{ha}^{-1}\right)$ as sole crops in the legume family $\left(1216 \mathrm{~kg} \mathrm{ha}^{-1}\right)$, averaged across $2 \mathrm{yr}$. The land equivalent ratios (LERs) for all mixtures in 2011 were $>1.0$, indicating mixtures were more productive than the individual components grown as sole crops. Improved performance in mixture may be related to the ecological resilience of mixed species communities in response to extreme weather events, such as hail. Partial LERs of species in the mustard family were consistently greater than those in the legume family, indicating that mustards dominated the mixtures. Results provide the basis for yield-stability rankings of spring-sown cover crop species and mixtures for the western Corn Belt.
\end{abstract}

$\mathrm{C}$ OVER CROPS HAVE been shown to provide a variety of benefits within agroecosystems. These include reduced soil erosion, increased biological diversity (e.g., microbes, insects, and birds), increased nutrient cycling and biological nitrogen fixation, increased soil organic matter, improved weed control, and increased crop yields (Pimentel et al., 1992, 1995; Sainju and Singh, 1997; Williams II et al., 1998; Altieri, 1999; Reddy et al., 2003; Teasdale et al., 2007). While cover crops may provide a number of agronomic and environmental benefits, achieving these benefits (e.g., weed suppression) often depends on establishing a highly productive cover crop community (Teasdale et al., 1991). Planting multi-species cover crop mixtures may be a viable solution for increasing the ecological stability and resilience of cover crop communities, which can contribute to higher and more consistent productivity.

Production benefits of multi-species plant communities include the potential for increased resource-use efficiency and crop yields (Francis, 1986). Intercropping systems typically include the production of two crop species (e.g., one cereal grain and one legume species) within a given field in the same season, most commonly oriented in alternating rows or strips of rows (e.g., Chen et al., 2004). While there are logistical challenges related to planting and harvesting intercrop systems, the potential

Dep. of Agronomy and Horticulture, Univ. of Nebraska- Lincoln, Lincoln, NE 68583. Received 27 Dec. 2011.*Corresponding author (sam.wortman@ huskers.unl.edu).

Published in Agron. J. 104:699-705 (2012)

Posted online 7 Mar. 2012

doi:10.2134/agronj2011.0422

Copyright (c) 2012 by the American Society of Agronomy, 5585 Guilford Road, Madison, WI 53711. All rights reserved. No part of this periodical may be reproduced or transmitted in any form or by any means, electronic or mechanical, including photocopying, recording, or any information storage and retrieval system, without permission in writing from the publisher. for increased yield of the entire system makes these potentially attractive cropping systems when labor and appropriate equipment are available. Indeed, there are many examples of intercropping systems that have demonstrated greater grain or forage yield compared to monoculture systems on an equivalent land area basis (Ikeorgu et al., 1989; Chen et al., 2004; Agegnehu et al., 2006; Ghosh et al., 2006). There are several potential mechanisms contributing to the increased yield observed in intercropping systems, including increased resource-use efficiency (light and soil resources) and increased ecological stability and resilience (Reddy and Willey, 1981; Tilman, 1996; Trenbath, 1999; Szumigalski and Van Acker, 2008). While two-species intercropping systems are most common, there are potential benefits associated with further increases in plant community diversity including increased productivity, community stability, and nutrient-use efficiency (Tilman, 1996; Tilman et al., 1997, 2001).

Multi-species cover cropping systems have been tested in previous studies, but most research was not designed to quantify the benefits of increasing cover crop diversity. Typically, cover crop mixture studies compare monoculture species with biculture combinations of those species (Akemo et al., 2000; Creamer and Baldwin, 2000; Odhiambo and Bomke, 2001; Kuo and Jellum, 2002). While there has been some focus on more diverse mixtures of cover crops (Creamer et al., 1997; Teasdale and Abdul-Baki, 1998; Madden et al., 2004), characterization of the benefits associated with increasing diversity are often limited to simple dry weight comparisons.

Many studies have demonstrated increased productivity of cover crop mixtures relative to monoculture cover crops, but the differences were likely due in part to higher seeding rates in the mixtures (Teasdale and Abdul-Baki, 1998; Odhiambo and Bomke, 2001; Kuo and Jellum, 2002). To accurately evaluate 
benefits of mixtures and the contributions of individual species to the mixtures, seeding rates of the mixtures should be proportional to the monocultures via a substitutive approach to avoid the confounding effects of variable seeding densities (e.g., seeding rate for a component of the mixture should be equal to its monoculture seeding rate divided by the number of species in the mixture; Jolliffe, 2000). It is possible that some other optimum seeding density or mixture proportion exists for cover crop mixtures, but addressing this question requires an additive seeding approach which would limit the utility of intercropping indices like the land equivalent ratio (Jolliffe, 2000). Moreover, a fully additive seeding approach to mixture seeding rates (combining $1 \mathrm{x}$ rates of each species) would be impractical and cost prohibitive for farmers.

Many cover crop mixture studies fail to include monoculture control treatments necessary to evaluate the potential benefits or antagonisms of the different mixtures (Creamer et al., 1997; Madden et al., 2004). Similarly, many of these studies do not quantify the productivity of the mixtures, or the individual components of the mixture, relative to sole cropped cover crops on an equivalent land area basis as calculated in traditional intercropping studies (Teasdale and Abdul-Baki, 1998; Creamer and Baldwin, 2000; Odhiambo and Bomke, 2001; Kuo and Jellum, 2002). Instead, the dry weights of each mixture and sole crop are typically reported; such methods provide limited information about the relative contribution or aggressiveness of each species in a cover crop mixture.

The aim of this study was to quantify the productivity and stability of spring-sown cover crop mixtures relative to sole cropped cover crops in the western Corn Belt, and to identify those species contributing to or detracting most from mixture productivity. With respect to this objective, we hypothesized that increasing cover crop diversity will increase cover crop productivity and stability.

\section{MATERIALS AND METHODS}

To accomplish this objective, a rainfed field experiment was conducted at the University of Nebraska-Lincoln Agricultural Research and Development Center near Mead, NE, in 2010 and 2011. Dominant soil type at the site is a Sharpsburg silty clay loam (fine, smectitic, mesic Typic Argiudoll; $\mathrm{pH}=6.3$, organic matter content $=3.6 \%$ ) with 0 to $5 \%$ slopes. The experimental layout was a randomized complete block design with four replications and 12 cover crop treatments. Experimental units were 3 by $3 \mathrm{~m}$ and randomized within each replication. Cover crop treatments included eight individual cover crop species and four mixtures of these species (Table 1). Cover crops used belong to either the Fabaceae (legume) or Brassicaceae (mustard) plant families. Mixtures were a 1:1 ratio of legume and mustard species where, for example, the eight species mixture included four legume species and four mustard species. The four cover crop mixtures ranged from two to eight species with an objective to quantify the effects of increasing plant diversity. The seeding rates for individual species in a mixture were determined by dividing the recommended seeding rate for that species by the number of species in mixture (Table 1), previously described as the substitutive approach. Recommended seeding rates for individual species were obtained from a combination of USDA Natural Resource Conservation Service, Cooperative Extension, cover crop seed distributor, and farmer recommendations. If recommendations among sources differed, values were averaged to determine the most appropriate seeding rate. Most recommendations were based on an assumption of drilled seeding methods. However, cover crops in this study were broadcast seeded; therefore, drilled seeding recommendations were increased by approximately $20 \%$ to compensate for reduced plant stands when using broadcast seeding methods (Clarke et al., 1978).

Cover crops were broadcast planted by hand and surface incorporated with a John Deere "cultipacker" (Deere and Company, Moline, IL) on 30 Mar. 2010 and 21 Mar. 2011. Plants received no supplemental irrigation or nutrition throughout the growing period, but large weeds were removed by hand from experimental units on a biweekly basis to limit competitive effects from noncover crop species. Plants were harvested on 25 May 2010 and 31 May 2011 from two randomly placed quadrats $\left(0.19 \mathrm{~m}^{2}\right)$ in each experimental unit. This harvest time was intended to simulate the termination period for a cover crop grown before summer annual crop species \{e.g., soybean [Glycine max (L.) Merr.], sorghum [Sorghum bicolor (L.) Moench], sunflower [Helianthus annuus L.] , or possibly maize [Zea mays L.]\}. Shortly following cover crop harvest and sampling, shoot dry weights were determined for sole crops and individual species within all mixtures by drying samples at $54^{\circ} \mathrm{C}$ to constant mass and weighing each sample.

The land equivalent ratio (LER) was used to compare the productivity of sole cropped cover crops to those cover crops planted in mixture. The LER indicates the relative amount of land required when growing sole crops to achieve the productivity observed in the mixture (Willey and Osiru, 1972).

Table I. Common name, scientific name, and seeding rates for eight cover crop species planted as sole crops (SC) or mixtures (2CC, 4CC, 6CC, and 8CC) in 2010 and 2011 near Mead, NE.

\begin{tabular}{|c|c|c|c|c|c|c|}
\hline \multirow{2}{*}{$\begin{array}{c}\text { Common } \\
\text { name }\end{array}$} & \multirow{2}{*}{$\begin{array}{c}\text { Scientific } \\
\text { name }\end{array}$} & \multicolumn{5}{|c|}{ Cover crop seeding rate } \\
\hline & & SC & $2 C C$ & $4 C C$ & $6 C C$ & $8 C C$ \\
\hline & & & & $\mathrm{kg} \mathrm{ha}^{-1}$ & & \\
\hline Hairy vetch & Vicia villosa Roth & 44.8 & 22.4 & 11.2 & 7.5 & 5.6 \\
\hline Idagold mustard & Sinapus alba $\mathrm{L}$. & 13.4 & 6.7 & 3.4 & 2.2 & 1.7 \\
\hline Field pea & Pisum sativum $\mathrm{L}$. & 112.0 & & 28.0 & 18.7 & 14.0 \\
\hline Pacific gold mustard & Brassica juncea (L.) Czern. \& Coss. & 8.8 & & 2.2 & 1.7 & I.I \\
\hline Crimson clover & Trifolium incarnatum $\mathrm{L}$. & 28.2 & & & 4.7 & 3.5 \\
\hline Oilseed radish & Raphanus sativus L. & 16.8 & & & 2.8 & 2.1 \\
\hline Chickling vetch & Lathyrus sativus $\mathrm{L}$. & 67.2 & & & & 8.4 \\
\hline Dwarf essex rape & Brassica napus $\mathrm{L}$. & 13.6 & & & & 1.7 \\
\hline
\end{tabular}


The LER is widely considered a robust and useful indicator of mixture productivity relative to sole crops (Bedoussac and Justes, 2011). The LER is typically used to evaluate marketable yield in intercropping systems, but to our knowledge has not been previously applied in the evaluation of diverse cover crop mixtures. Total LER is calculated as:

$$
\mathrm{LER}=\mathrm{LER}_{i}+\mathrm{LER}_{j} \ldots .+\mathrm{LER}_{n}
$$

where $\mathrm{LER}_{i}$ is the partial LER of species $i, \mathrm{LER}_{j}$ is the partial LER of species $j$, and so forth for $n$ number of species. Partial LER is calculated as:

$$
\mathrm{LER}_{i}=Y_{M I i} / Y_{S C i}
$$

where $Y_{M I i}$ is the yield of species $i$ planted in mixture and $Y_{S C i}$ is the yield of species $i$ planted as a sole crop. A total LER value $>1.0$ indicates the mixture was more productive than the component sole crops, whereas a value $<1.0$ suggests sole crops were more productive (e.g., antagonistic effects). For example, a total LER value of 1.5 suggests that 15 ha of sole cropped cover crops (the components of the mixture) would need to be planted to achieve an equivalent level of productivity (yield) achievable on 10 ha when all species are grown together in a mixture. The partial LER values for individual species in a mixture were also used to compare the relative contribution or competitive ability of each species (Bedoussac and Justes, 2011).

To accomplish all objectives, shoot dry weight data, LER, and partial LER values were analyzed with the MIXED procedure in SAS (SAS Institute, Cary, NC). Fixed effects in the model included cover crop treatment and year, and the random effect was the interaction of block $\times$ year. Least squares means and population standard errors were reported for all cover species and mixtures for statistical comparisons. Ecological stability of cover crop communities was compared using the coefficient of variation $(\mathrm{CV})$ for each cover crop treatment pooled across replications $(n=4)$ and years $(n=2)$. A lower CV implies less variation about the mean and greater ecological stability (Tilman et al., 1998). Lastly, orthogonal contrasts were used to compare the productivity (shoot dry weights) and stability (CVs) of mixtures vs. sole crops (legumes and/or mustards).

\section{RESULTS AND DISCUSSION Productivity and Stability of Sole Crops and Mixtures}

Shoot dry weight of sole cropped cover crop species in 2010 ranged from $397 \pm 252 \mathrm{~kg} \mathrm{ha}^{-1}$ (mean \pm one population standard error) for chickling vetch (Lathyrus sativus L.) to $3175 \pm 252 \mathrm{~kg} \mathrm{ha}^{-1}$ for Idagold mustard (Sinapus alba L.) (Fig. 1). Shoot dry weight of mustard cover crop species $\left(2757 \pm 126 \mathrm{~kg} \mathrm{ha}^{-1}\right)$ was consistently greater than legumes $\left(1127 \pm 126 \mathrm{~kg} \mathrm{ha}^{-1}\right)$ in 2010 . However, an orthogonal contrast of mixtures vs. mustard sole crops indicated that shoot dry weight of mustard sole crops was not different from the average shoot dry weight of mixtures $\left(2709 \pm 126 \mathrm{~kg} \mathrm{ha}^{-1}\right)$. Shoot dry weight of sole cropped cover crop species in 2011 ranged from $1076 \pm 252 \mathrm{~kg} \mathrm{ha}^{-1}$ for chickling vetch to $2556 \pm 252 \mathrm{~kg} \mathrm{ha}^{-1}$ for oilseed radish (Raphanus sativus L.) (Fig. 1). Consistent with 2010, shoot dry weight of mustard cover crop species
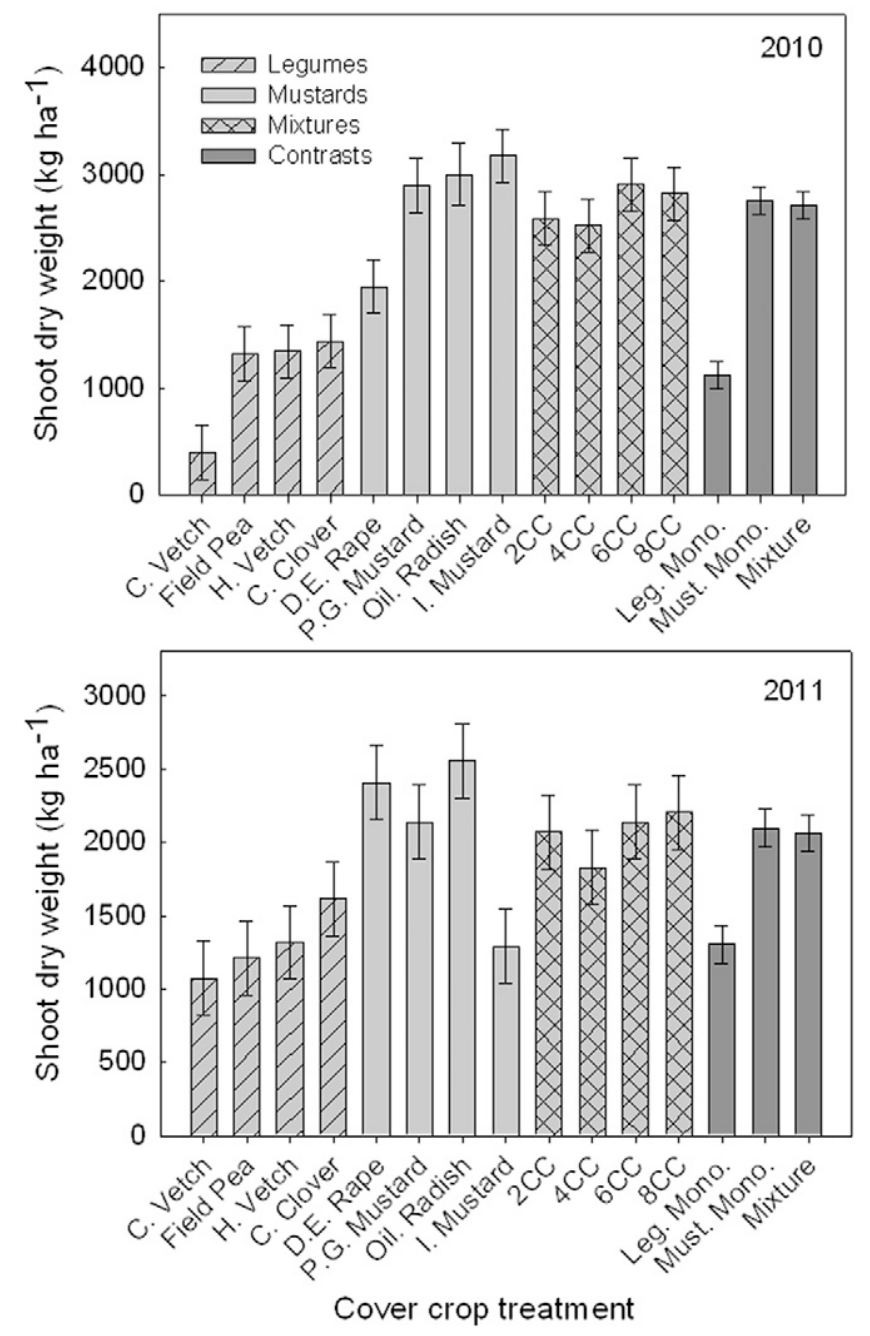

Fig. I. Shoot dry weights ( $\left.\mathrm{kg} \mathrm{ha}^{-1}\right)$ of eight cover crop species and four possible mixtures of the eight species in 2010 and $201 \mathrm{I}$ (see Table I for species and mixture components and seeding rates). An orthogonal contrast of monoculture treatments $(n=$ 32 ) vs. mixture treatments $(n=16)$ is presented for each year. Error bars represent the standard error of the mean.

$\left(2099 \pm 126 \mathrm{~kg} \mathrm{ha}^{-1}\right)$ was consistently greater than legumes $\left(1305 \pm 126 \mathrm{~kg} \mathrm{ha}^{-1}\right)$ but not different from the average shoot dry weight of the mixtures $\left(2062 \pm 126 \mathrm{~kg} \mathrm{ha}^{-1}\right)$. Within the cover crop mixtures, productivity did not increase with diversity as there was no difference in shoot dry weight among any of the four possible mixtures in 2010 or 2011 (Fig. 1).

Overall, the productivity of all cover crops in this study was far greater than the previously reported dry matter yields of springsown cover crops in eastern Nebraska (Power and Koerner, 1994). The greater productivity observed in this study may be related to the earlier cover crop planting date used in this study (late March) compared to the delayed plantings (late April and early May) tested by Power and Koerner (1994).

The CV, accounting for spatial (replication) and temporal (year) variation differed among individual cover crop treatments. Among legume species, CV values ranged from 16.9 to $55.2 \%(\mu=33.5 \%)$ for crimson clover (Trifolium incarnatum L.) and chickling vetch, respectively. Among mustard species, values ranged from 20.6 to $46.6 \%(\mu=31.6 \%)$ for oilseed radish and Idagold mustard, respectively (Fig. 2). The variability of Idagold mustard was related to its susceptibility to hail damage. 


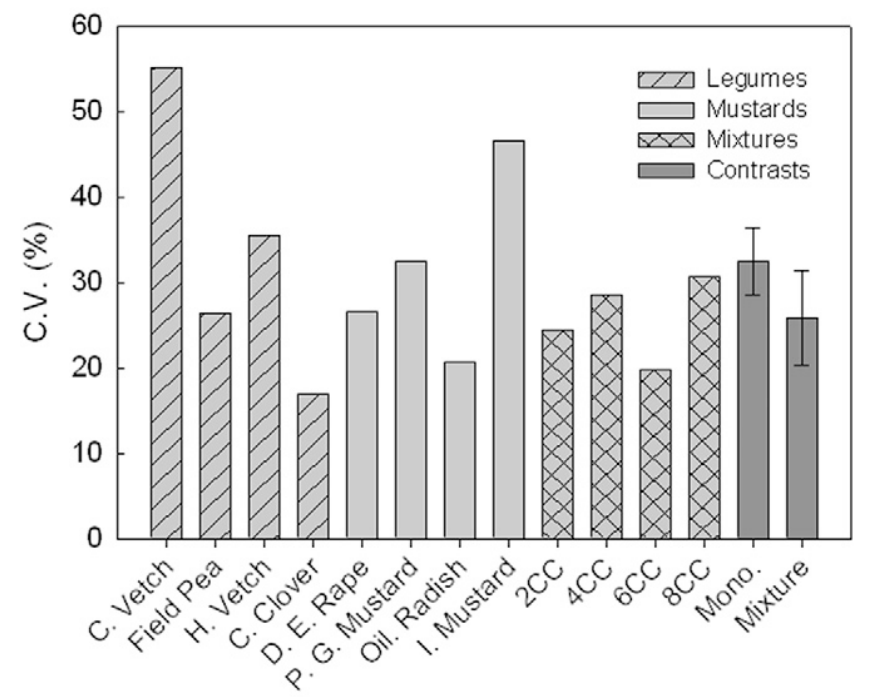

Cover crop treatments

Fig. 2. Coefficient of variation (CV \%) for each cover crop monoculture and mixture combination (two, four, six, and eight species) pooled across replications and years $(n=8)$. The mean and standard error of CVs pooled within monoculture treatments $(n=8)$ and within mixture treatments $(n=4)$ is also presented.

While Idagold mustard was the most productive cover crop in 2010, a 12 May 2011 hail storm limited its productivity in 2011. The hail storm was damaging to all cover crop treatments, but Idagold mustard seemed to recover much more slowly than the other species and mixtures. The CV for cover crop mixtures only ranged from 19.8 to $30.7 \%$ ( $\mu=25.9 \%$ ), but orthogonal contrasts of mixtures vs. monocultures indicated no difference $(p=0.35)$ in the stability of the two cover cropping strategies. Similarly, the CV was relatively uninfluenced by increasing diversity within the mixtures (Fig. 2). It is possible that the number of replications $(n=4)$ and years $(n=2)$ was insufficient to detect differences in the stability of different monoculture and mixture cover crop strategies. A more robust measure of stability would require data from a long-term or multi-site experiment. Nonetheless, knowledge of the spatial and temporal variability (though limited) may be useful in selecting an appropriate cover crop species or mixture.

\section{Land Equivalent Ratios for Mixtures and Mixture Components}

The LER was not affected by cover crop mixture or the interaction of mixture by year. However, LER was influenced by year and was greater in $2011(\mathrm{LER}=1.38 \pm 0.09)$ than in $2010($ LER $=1.05 \pm 0.09)$ for all mixtures (Fig. 3). All mixtures across both years were $\geq 1.0$, while all mixtures in 2011 were $>1.0$. A value $>1.0$ suggests the mixture resulted in more efficient use of land than the alternative of growing the individual mixture components as sole crops. The primary difference between 2010 and 2011 was the 12 May 2011 hail storm that severely damaged all cover crop treatments. Cover crops were not harvested until 31 May 2011 (approximately $1 \mathrm{wk}$ later than the harvest date in 2010), in an effort to allow the cover crops to recover and regrow after the substantial hail damage. While the objective of this study was not to measure the ecological resilience of cover crop mixtures, the 2011 hail storm did provide anecdotal information

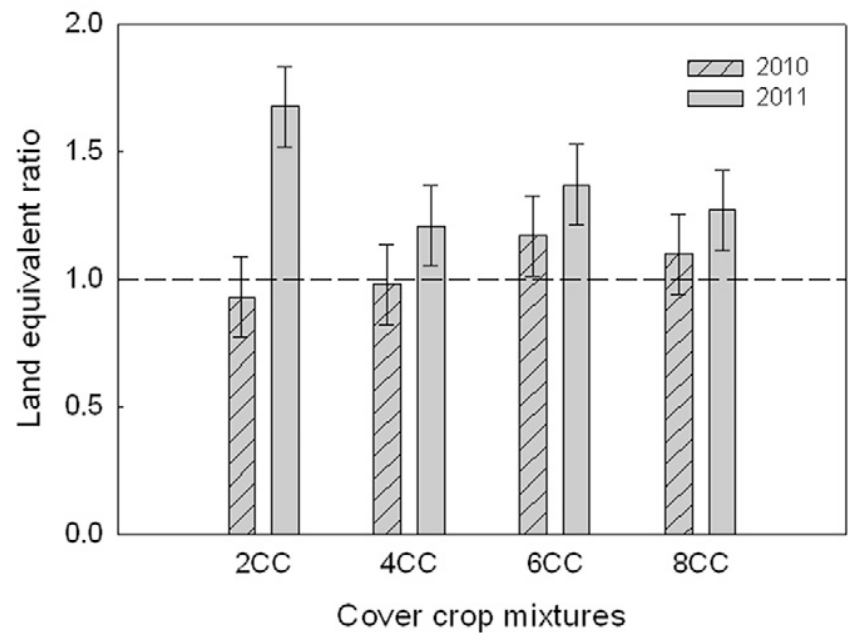

Fig. 3. Total land equivalent ratios (LER) for the four cover crop mixtures (combinations of two, four, six, and eight species) in 2010 and 20II. Error bars represent the standard error of the mean. A LER value $>I .0$ suggests a given mixture is more productive than its component sole crops.

about the ability of these species and mixtures to recover after extreme perturbation. Given our observations, we hypothesize that the increased LER in 2011 from 2010 is directly related to the potential for increased resilience in mixtures relative to sole crops. Indeed, the ability to quickly recover from disturbance (resiliency) can contribute to productivity and is often a characteristic of diverse plant communities (Lavorel, 1999; Hooper et al., 2005).

The over-yielding potential of plant species grown in mixture for agricultural use is consistent with many previous studies (e.g., Ikeorgu et al., 1989; Chen et al., 2004; Agegnehu et al., 2006; Ghosh et al., 2006). Undoubtedly, over-yielding characteristics have been observed for decades in cover crop mixtures, but the documentation of this phenomenon requires appropriate data collection and indices like the LER. To our knowledge, this is the first reported evidence of over-yielding properties in a mixture of plant species specifically designed for cover crop use. Contrary to our expectations, LER did not increase with diversity of the mixture (from two to eight species). Increasing community diversity has been shown to increase resource-use efficiency, primary productivity (Tilman et al., 1997; Tilman et al., 2001), and presumably the efficiency of land use (LER), but this was not observed here.

Partial LERs were consistently greater for mustards in mixture compared to legumes (Table 2). Idagold mustard was the most competitive cover crop species in all mixtures as indicated by the highest (or among the highest) partial LER pooled across both years $(0.98,0.43,0.48$, and 0.33 in the 2CC, 4CC, 6CC, and 8CC mixtures, respectively). In contrast, all legume species were least competitive in all mixtures pooled across both years $(0.33,0.14,0.10$, and 0.07 in the 2CC, 4CC, 6CC, and 8CC mixtures, respectively; Table 2). If all species were contributing equally to the productivity of a mixture, we would expect the partial LER of a given species to be $0.5,0.25,0.167$, and 0.125 in the two, four, six, and eight species mixtures, respectively. A partial LER greater than these expected values for species $i$ within a given mixture suggests species $i$ was benefiting from the increased interspecific and reduced intraspecific competitive environment of the multispecies mixture. Conversely, a partial LER less than these 
Table 2. Partial land equivalent ratios (LER $)$ for eight cover crop species in the four possible mixtures (2CC, 4CC, 6CC, and 8CC) pooled across 2010 and $201 \mathrm{l}$. Numbers in parentheses indicate the standard error of the least squares mean. Different letters indicate differences among means within a mixture.

\begin{tabular}{lcccc}
\hline \multicolumn{1}{c}{$\begin{array}{c}\text { Cover crop } \\
\text { species }\end{array}$} & \multicolumn{4}{c}{ Cover crop mixture } \\
\cline { 2 - 5 } & 2CC & 4CC & 6CC & 8CC \\
\hline Hairy vetch & $0.33(0.14) \mathrm{b}$ & $0.15(0.06) \mathrm{b}$ & $0.08(0.05) \mathrm{d}$ & $0.07(0.03) \mathrm{c}$ \\
Idagold mustard & $0.98(0.14) \mathrm{a}$ & $0.43(0.06) \mathrm{a}$ & $0.48(0.05) \mathrm{a}$ & $0.33(0.03) \mathrm{a}$ \\
Field pea & & $0.13(0.06) \mathrm{b}$ & $0.15(0.05) \mathrm{cd}$ & $0.10(0.03) \mathrm{c}$ \\
Pacific gold mustard & & $0.39(0.06) \mathrm{a}$ & $0.33(0.05) \mathrm{b}$ & $0.19(0.03) \mathrm{b}$ \\
Crimson clover & & & $0.07(0.05) \mathrm{d}$ & $0.04(0.03) \mathrm{c}$ \\
Oilseed radish & & & $0.17(0.05) \mathrm{c}$ & $0.21(0.03) \mathrm{b}$ \\
Chickling vetch & & & & $0.06(0.03) \mathrm{c}$ \\
Dwarf essex rape & & & & $0.19(0.03) \mathrm{b}$ \\
Total LER & & & $1.27(0.1 \mathrm{I})$ & $1.19(0.1 \mathrm{I})$ \\
\hline
\end{tabular}

expected values would suggest that species $i$ is inhibited more by the interspecific competitive interactions in the mixture. Partial LER values for the mustards were always greater than or equal to these expected values, suggesting all mustard species used in this experiment benefited from the mustard-legume mixture combinations. In contrast, the legumes were always less than or equal to these expected values suggesting the legume species used in this experiment tended to be negatively influenced by the competitive interactions in the mustardlegume mixture combinations.

While these results suggest mustards benefited most from the mixture combinations, it is important to note that total LER was always $\geq 1.0$. Despite the negative competitive effects on most legume species, the substantial gain in mustard productivity in mixture (relative to monoculture) led consistently to $L E R$ values $\geq 1.0$. These results are congruent with the results of Szumigalski and Van Acker (2008) who found that canola (a mustard species) was quite competitive and tended to over-yield in mixture with field pea (Pisum sativum $\mathrm{L}$.) and wheat (Triticum aestivum $\mathrm{L}$.). The over-yielding effect of the mustards when grown in mixture with legumes may have at least two possible explanations. First, the canopy architecture of mustards compared to legumes may give the mustards a competitive advantage in these mixtures (Tremmel and Bazzaz, 1993). The shoot and canopy architecture of the mustard species used in this experiment is generally erect with large leaves, whereas the legume species are low growing (vine, rosette, or prostrate growth habit) with relatively small leaves. The morphology of mustard species creates a very competitive environment for light resources (Szumigalski and Van Acker, 2008); thus, when the mustard densities were reduced and replaced with a less light competitive species the mustards were released from this strong intraspecific competitive interaction. A second explanation may be that the monoculture seeding densities for the mustard species were too high, and reducing the proportional seeding densities in the mixtures created an over-yielding environment. Many plant species exhibit a quadratic yield response to increasing plant density; therefore, it is possible the seeding densities in this study were beyond optimum (Cox, 1996). However, the recommended seeding rates for the mustard species were consistent across many information resources, and it is reasonable to assume that the densities used in this study were sufficiently close to optimum.

\section{Cover Crop Choice}

When making decisions about which cover crop or mixture of cover crops to plant, one must consider both the potential productivity and ecological stability of all available options. To aid in a simple and effective cover crop selection process, rankings of each cover crop species and mixture were determined for shoot yield in 2010 and 2011, yield stability, and for a combined measure of yield and stability with varying weights distributed between the two variables (1:1, 2:1, and 4:1 for yield/stability). This method and similar ranking methods have been used in the selection of high yielding and stable maize hybrids (Kang, 1988; Kang and Pham, 1991). The ranking system used by Kang and Pham (1991), which combined yield and stability ranks, provides an example of how the "best" or highest ranked option can vary depending on the relative importance placed on yield and stability. Consistent with the results of Kang and Pham (1991), the relative ranking of cover crop options in this experiment varied depending on the importance (weight) placed on yield or stability (Table 3). Kang and Pham (1991) found that placing more than a 2x weight on yield (relative to stability) results in a ranking that tends to reflect solely the yield ranks. In this study, the 4:1 yield-stability rankings were only slightly different from the yield rankings; however, the 1:1 and 2:1 yield-stability rankings were substantially different from both the $4: 1$ yield-stability rankings and yield rankings. Therefore, to choose a cover crop option that is most likely to demonstrate stability over time, in addition to high productivity, one should choose a combined yield-stability ranking with a 1:1 or 2:1 relative weight assigned to yield and stability ranks, respectively (Kang, 1988).

When considering productivity and stability, regardless of the relative weight of each, oilseed radish seems to be the most promising cover crop option observed in this study, followed by the six-species mixture (6CC; Table 3). In contrast, chickling vetch and hairy vetch (Vicia villosa Roth) grown alone seem to be the two least promising cover crop options when considering both yield and stability (Table 3). These rather simple categorical rankings do not account for the overyielding characteristics of cover crop mixtures identified by the LER or the potential for biological nitrogen fixation of legumes. However, depending on the management objective of the farmer, these rankings could be expanded to include additional factors. Thus, the rankings presented here should instead be used as a starting point for recommendations. It is 
Table 3. Rankings for each cover crop option considering shoot yield (20I0 and 20II), yield stability (CV), and a combination of yield and stability with varying weights (I:I, $2: 1$, and $4: 1)$ attributed to each.

\begin{tabular}{|c|c|c|c|c|c|c|}
\hline \multirow{2}{*}{$\begin{array}{l}\text { Cover } \\
\text { crop }\end{array}$} & \multicolumn{2}{|c|}{ Shoot yield } & \multirow[b]{2}{*}{ CV } & \multicolumn{3}{|c|}{ Proportion of yield to CV } \\
\hline & 2010 & 2011 & & I:I & $2: 1$ & 4:1 \\
\hline \multicolumn{7}{|l|}{ Legumes } \\
\hline Crimson clover & 9 & 8 & 1 & 3 & 7 & 8 \\
\hline Field pea & II & II & 5 & 9 & 10 & II \\
\hline Hairy vetch & 10 & 9 & 10 & 11 & 11 & 10 \\
\hline Chickling vetch & 12 & 12 & 12 & 12 & 12 & 12 \\
\hline \multicolumn{7}{|l|}{ Mustards } \\
\hline Oilseed radish & 2 & 1 & 3 & I & I & I \\
\hline Dwarf essex rape & 8 & 2 & 6 & 5 & 3 & 5 \\
\hline Pacific gold mustard & 4 & 4 & 9 & 7 & 6 & 4 \\
\hline Idagold mustard & 1 & 10 & II & 10 & 9 & 7 \\
\hline \multicolumn{7}{|l|}{ Mixtures } \\
\hline $2 \mathrm{CC}$ & 6 & 6 & 4 & 4 & 3 & 6 \\
\hline $4 C C$ & 7 & 7 & 7 & 8 & 8 & 8 \\
\hline $6 C C$ & 3 & 4 & 2 & 2 & 2 & 2 \\
\hline $8 C C$ & 5 & 3 & 8 & 6 & 3 & 3 \\
\hline
\end{tabular}

also interesting to note that cover crop mixtures were never ranked higher than second, but never lower than eighth (of 12). While mixtures may not provide the greatest potential for maximum productivity in a given year, they do seem to buffer against unacceptably low productivity.

\section{Conclusions}

The mustard species \{Idagold mustard, Pacific Gold mustard [Brassica juncea (L.) Czern. \& Coss.], oilseed radish, and dwarf essex rape [B. napus L.] $\}$ tested here proved to be fast growing, competitive, and productive cover crops well suited for early spring growth in the western Corn Belt. Conversely, the legume species tested (hairy vetch, field pea, crimson clover, and chickling vetch) were far less competitive and almost half as productive as the mustards. While the legume species were generally less impressive, the potential for biological $\mathrm{N}$ fixation and utility as a green manure may compensate for the limited productivity. Though generally lower, yield variability of mixtures was not significantly different from monocultures. Instead, the primary benefit of cover crop mixtures seemed to be the potential for over-yielding (LER values $>1.0$ ) that was observed in 1 yr of this research.

This study provides specific recommendations about productive and stable spring-sown cover crop options for the western Corn Belt, but also offers broad evidence and insight regarding the ecological benefits of cover crop mixtures that should be applicable to a variety of cover crop species, mixture combinations, planting dates, seasonal weather, and agroecoregions. Ultimately, cover crop species or mixture choice will depend on the specific management objective and the available threshold for risk. These results provide an example of the information necessary for making these decisions as part of a production package.

\section{ACKNOWLEDGMENTS}

The authors wish to acknowledge Tom Galusha for technical support and The Ceres Trust Organic Research Initiative for project funding.

\section{REFERENCES}

Agegnehu, G., A. Ghizaw, and W. Sinebo. 2006. Yield performance and land-use efficiency of barley and faba bean mixed cropping in Ethiopian highlands. Eur. J. Agron. 25:202-207. doi:10.1016/j.eja.2006.05.002

Akemo, M.C., E.E. Regnier, and M A. Bennett. 2000. Weed suppression in spring-sown rye (Secale cereale)-pea (Pisum sativum) cover crop mixes. Weed Technol. 14:545-549. doi:10.1614/0890-037X(2000)014[0545: WSISSR]2.0.CO;2

Altieri, M. 1999. The ecological role of biodiversity in agroecosystems. Agr. Ecosyst. Environ. 74:19-31. doi:10.1016/S0167-8809(99)00028-6

Bedoussac, L., and E. Justes. 2011. A comparison of commonly used indices for evaluating species interactions and intercrop efficiency: Application to durum wheat-winter pea intercrops. Field Crop Res. 124:25-36. doi:10.1016/j.fcr.2011.05.025

Chen, C., M. Westcott, K. Neill, D. Wichman, and M. Knox. 2004. Row configuration and nitrogen application for barley-pea intercropping in Montana. Agron. J. 96:1730-1738. doi:10.2134/agronj2004.1730

Clarke, J.M., F.R. Clarke, and G.M. Simpson. 1978. Effects of method and rate of seeding on yield of Brassica napus. Can. J. Plant Sci. 58:549-550. doi:10.4141/cjps78-081

Cox, W.J. 1996. Whole-plant physiological and yield responses of maize to plant density. Agron. J. 88:489-496. doi:10.2134/agronj1996.0002196 $2008800030022 x$

Creamer, N.G., and K.R. Baldwin. 2000. An evaluation of summer cover crops for use in vegetable production systems in North Carolina. HortScience 35:600-603.

Creamer, N.G., M.A. Bennett, and B.R. Stinner. 1997. Evaluation of cover crop mixtures for use in vegetable production systems. HortScience 32:866-870.

Francis, C.A., editor. 1986. Multiple cropping systems. Macmillan, New York.

Ghosh, P.K., M.C. Manna, K.K. Bandyopadhyay, Ajay, A.K. Tripathi, R.H. Wanjari, K.M. Hati, A.K. Misra, C.L. Acharya, and A. Subba Rao. 2006. Interspecific interaction and nutrient use in soybean/sorghum intercropping system. Agron. J. 98:1097-1108. doi:10.2134/agronj2005.0328

Hooper, D.U., F.S. Chapin, J.J. Ewel, A. Hector, P. Inchausti, S. Lavorel, J.H. Lawton, D.M. Lodge, M. Loreau, S. Naeem, B. Schmid, H. Setälä, A.J. Symstad, J. Vandermeer, and D.A. Wardle. 2005. Effects of biodiversity on ecosystem functioning: A consensus of current knowledge. Ecol. Monogr. 75:3-35. doi:10.1890/04-0922

Ikeorgu, J.E.G., H.C. Ezumah, and T.A.T. Wahua. 1989. Productivity of species in cassava/maize/okra/egusi melon complex mixtures in Nigeria. Field Crop Res. 21:1-7. doi:10.1016/0378-4290(89)90035-X

Jolliffe, P. A. 2000. The replacement series. J. Ecol. 88:371-385. doi:10.1046/j.1365-2745.2000.00470.x

Kang, M.S. 1988. A rank-sum method for selecting high-yielding, stable corn genotypes. Cereal Res. Commun. 16:113-115. 
Kang, M.S., and H.N. Pham. 1991. Simultaneous selection for high yielding and stable crop genotypes. Agron. J. 83:161-165. doi:10.2134/agronj199 $1.00021962008300010037 \mathrm{x}$

Kuo, S., and E.J. Jellum. 2002. Influence of winter cover crop and residue management on soil nitrogen availability and corn. Agron. J. 94:501508. doi:10.2134/agronj2002.0501

Lavorel, S. 1999. Ecological diversity and resilience of Mediterranean vegetation to disturbance.Divers.Distrib.5:3-13.doi:10.1046/j.1472-4642.1999.00033.x

Madden, N.M., J.P. Mitchell, W.T. Lanini, M.D. Cahn, E.V. Herrero, S. Park, S.R. Temple, and M. Van Horn. 2004. Evaluation of conservation tillage and cover crop systems for organic processing tomato production. HortTechnology 14:243-250.

Odhiambo, J.J.O., and A.A. Bomke. 2001. Grass and legume cover crop effects on dry matter and nitrogen accumulation. Agron. J. 93:299-307. doi:10.2134/agronj2001.932299x

Pimentel, D., C. Harvey, P. Resosudarmo, K. Sinclair, D. Kurz, M. McNair, S. Crist, L. Shpritz, L. Fitton, R. Saffouriand, and R. Blair. 1995. Environmental and economic costs of soil erosion and conservation benefits. Science (Washington, DC) 267:1117-1123. doi:10.1126/ science. 267.5201 .1117

Pimentel, D., U. Stachow, D.A. Takacs, H.W. Brubaker, A.R. Dumas, J.J. Meaney, J.A.S. O’Neil, D.E. Onsi, and D.B. Corzilius. 1992. Conserving biological diversity in agricultural/forestry systems. BioScience 42:354362. doi: $10.2307 / 1311782$

Power, J.E., and P.T. Koerner. 1994. Cover crop production for several planting and harvest dates in eastern Nebraska. Agron. J. 86:1092-1097. doi:10.2134/agronj1994.00021962008600060031x

Reddy, K.N., R.M. Zablotowicz, M.A. Locke, and C.H. Koger. 2003. Cover crop, tillage, and herbicide effects on weeds, soil properties, microbial populations, and soybean yield. Weed Sci. 51: 987-994. doi:10.1614/ P2002-169

Reddy, M.S., and R.W. Willey. 1981. Growth and resource use studies in an intercrop of pearl millet/groundnut. Field Crop Res. 4:13-24. doi:10.1016/0378-4290(81)90050-2

Sainju, U.M., and B.P. Singh. 1997. Winter cover crops for sustainable agricultural systems: Influence on soil properties, water quality, and crop yields. HortScience 32: 21-28.
Szumigalski, A.R., and R.C. Van Acker. 2008. Land equivalent ratios, light interception, and water use in annual intercrops in the presence or absence of in-crop herbicides. Agron. J. 100:1145-1154. doi:10.2134/ agronj2006.0343

Teasdale, J.R., and A.A. Abdul-Baki. 1998. Comparison of mixtures vs. monocultures of cover crops for fresh-market tomato production with and without herbicide. HortScience 33:1163-1166.

Teasdale, J.R., C.E. Beste, and W.E. Potts. 1991. Response of weeds to tillage and cover crop residue. Weed Sci. 39: 195-199.

Teasdale, J.R., L.O. Brandsaeter, A. Calegari, and F. Skora Neto. 2007. Cover crops and weed management. In: M.K. Upadhyaya and R.E. Blackshaw, editors, Non-chemical weed management. CAB International, Wallingford, UK.

Tilman, D. 1996. Biodiversity: Population versus ecosystem stability. Ecology 77:350-363. doi: $10.2307 / 2265614$

Tilman, D., C.L. Lehman, and C.E. Bristow. 1998. Diversity-stability relationships: Statistical inevitability or ecological consequence? Am. Nat. 151:277-282. doi:10.1086/286118

Tilman, D., C.L. Lehman, and K.T. Thomson. 1997. Plant diversity and ecosystem productivity: Theoretical considerations. P. Natl. Acad. Sci. USA 94:1857-1861. doi:10.1073/pnas.94.5.1857

Tilman, D., P.B. Reich, J. Knops, D. Wedin, T. Mielke, and C. Lehman. 2001. Diversity and productivity in a long-term grassland experiment. Science (Washington, DC) 294:843-845. doi:10.1126/science.1060391

Tremmel, D.C., and F.A. Bazzaz. 1993. How neighbor canopy architecture affects target plant performance. Ecology 74:2114-2124. doi: $10.2307 / 1940856$

Trenbath, B.R. 1999. Multispecies cropping systems in India: Predictions of their productivity, stability, resilience and ecological sustainability. Agroforest. Syst. 45:81-107. doi:10.1023/A:1006285319817

Willey, R.W., and D.S.O. Osiru. 1972. Studies on mixtures of maize and beans (Phaseolus vulgaris) with particular reference to plant population. J. Agric. Sci. 79:517-529. doi:10.1017/S0021859600025909

Williams II, M.M., D.A. Mortensen, and J.W. Doran. 1998. Assessment of weed and crop fitness in cover crop residues for integrated weed management. Weed Sci. 46: 595-603. 